\title{
Epidemiological and Serological Aspects in Canine Toxoplasmosis in Animals with Nervous Symptoms
}

\author{
Adriana Falco de Brito, Luiz Carlos de Souza*, Aristeu Vieira da Silva*, Helio Langoni/+ \\ Faculdade de Ciências Agrárias, Universidade do Oeste Paulista, Presidente Prudente, SP, Brasil *Núcleo de Pesquisa em \\ Zoonoses, Departamento de Higiene Veterinária e Saúde Pública, Faculdade de Medicina Veterinária e Zootecnia, Unesp, Distrito \\ de Rubião Jr. s/no, $18610-240$ Botucatu, SP, Brasil
}

The presence of anti-Toxoplasma gondii IgM and IgG antibodies was studied in samples of blood serum taken from eighty dogs with nervous symptoms at the Serviço de Enfermidades Infecciosas dos Animais, Faculdade de Medicina Veterinária e Zootecnia, Unesp, Botucatu, São Paulo, Brazil. The frequency of IgG titers were 16 (13.7\%), 64 (13.7\%), and $256(5 \%)$, and for IgM titers were 16 (7.5\%), 64 (15\%), and 256 (8.7\%). Positive reactions were more frequent in the older animals, males, from a rural environment, in constant contact with small animals, principally birds and rodents. There was a higher frequency of a positive reaction in dogs fed with kitchen food, especially in those fed with raw ingredients. The most common neurological pictures were alterations in consciousness, in movement, and in the hand-cart test. The percentage of reagents with specific IgM antibodies was high, indicating active infections, but the possibility of co-infection with the distemper virus can not be discarded, and this may be a predisposing factor for toxoplasmosis infection, once the distemper virus has a potent immunosupressive action.

Key words: toxoplasmosis - canine - serology - epidemiology - nervous symptomology

Toxoplasmosis is a parasitic zoonosis with world-wide distribution, carried by Toxoplasma gondii, a protozoa that can infect man and warm-blooded animals, by the three forms of its life cycle: (1) orally, by the ingestion of oocysts, (2) by ingestion of cysts lodged in tissues of intermediate hosts, and (3) via the uterus, by transplacental transmission of tachyzoites. T. gondii can also be transmitted in products of blood origin, or by ingestion of tachyzoites in non-pasteurized goat milk (Tenter 1999).

Although the role of dogs in the spread of the disease has generally been considered as of secondary importance, intimate contact between man and dogs has led to much study (Svoboda \& Svobodová 1987). Martins and Viana (1998) highlight the importance of dogs in the epidemiological chain of the disease, through the habit of ingesting, and rolling in, cat feces, thus permitting transmission of oocysts by contact of the contaminated hide. Lindsay et al. (1997) demonstrated that after ingestion of $T$. gondii non-sporulate oocysts, these could pass through the intestinal tract of dogs, and be excreted in their infectious stage, re-enforcing the theory that dogs act as mechanical vectors of oocysts.

Germano et al. (1985) and Jackson et al. (1987) point out that the infection rate of the canine population is an indication of the domestic environment contamination by T. gondii, and the consequent risk to the human population, due to the fact that both humans and dogs are exposed to a common source of infection, represented by the environment and alimentary habits.

Infection in canines has been observed in many countries, demonstrating its cosmopolitan character (Guimarães et al. 1992). Toxoplasmic infection amounted to $91 \%$ in 657

\footnotetext{
${ }^{+}$Corresponding author. Fax: +55-14-6802.6075. E-mail: hlangoni@fmvz.unesp.br Received 6 February 2001 Accepted 28 August 2001
}

dogs in the city of Campinas, as detected by the indirect immunofluorescent antibody test (IFAT) (Germano et al. 1985). Ishizuka and Yasuda (1981) found 63.8\% positive antiT. gondii antibodies in 1,256 samples of street hounds captured by the Centro de Controle de Zoonoses in São Paulo. In Botucatu, São Paulo, Salata et al. (1985) analyzed serum of $47 \mathrm{dogs}$ by IFAT, finding $63.8 \%$ positive reactions.

In Belo Horizonte, Minas Gerais, during 1988-1990, from serum collected from 243 animals, at the College of Veterinary Medicine, Federal University of Minas Gerais, there were $47.3 \%$ positive reactions, $54.3 \%$ of those with titer 16 , $30.7 \%$ with 64 , and $9.65 \%$ with 256 (Guimarães et al. 1992).

Freire et al. (1992) found that of $254 \mathrm{dogs}$ from Londrina, Paraná, showing signs compatible with toxoplasmosis, 193 (75.9\%) were positive. The distribution of reagents to the IFAT showed the majority of titers between 16 and 1024. In the same city, Navarro et al. (1997) found 73 positive (23.4\%) of a total of 312 .

The characteristics of high infectivity and low pathogenicity of $T$. gondii justify the research realized as a function only of the measurement of levels of antibodies. Recent or active infection may be evidenced by high IgM titers, as 64 or above in samples with negative $\operatorname{IgG}$, or by demonstration of ascendant titers - fourfold or greater of IgG antibodies in paired serum samples (Dubey et al. 1990, Swango et al. 1992).

This work aimed to evaluate the presence of anti- $T$. gondii antibodies in dogs with nervous symptoms, and related this study to epidemiological data, and to the clinical neurology presented by the animals.

\section{MATERIALS AND METHODS}

Animals - Eighty dogs presenting nervous symptoms, being attended at the Serviço de Enfermidades Infecciosas dos Animais, Faculdade de Medicina Veterinária e Zootecnia, Unesp, Botucatu, São Paulo, were selected, regardless of breed, sex, or age, from January to December 1998.

Epidemiological and neurological data - Epidemiological data, and data from the neurological clinic, were collected and entries made according to the system of 
Svoboda and Svobodová (1987). The entries included identification (register number in the hospital, in the clinical center, name of the animal, owner's name and address), characterization of the animal (age, sex, breed), description of home environment (rural or urban, confined or with access to street, if confined paved or dirt yard), contact with other animals (cats, rodents, birds, other dogs, hunting habits), food (commercial alone; mixed with kitchen food; only kitchen prepared food, or leftover human food; raw meat, raw vegetables, or raw offal; ingestion of milk, pasteurized or raw, cow or goat). Neurological data include occurrences of convulsions, discriminated into large or small, consciousness, walking movements, the results of hand-cart tests, and reactions of pupils.

Collection of blood samples and serological examinations - Blood from the jugular vein, 15 to $20 \mathrm{ml}$, were collected without anticoagulant, serum separated by centrifugation at $3000 \mathrm{rpm}$ for $15 \mathrm{~min}$, and stored at $-20^{\circ} \mathrm{C}$ until serological examination.

Serological tests for IgM and IgG anti-T. gondii antibodies were carried out in the Serviço de Diagnóstico de Zoonoses, using the indirect fluorescent antibody test (IFAT), according to Camargo (1974). Serum samples were tested in dilutions of $1: 16,1: 64,1: 256,1: 1024$, and 1:4096, utilizing commercial anti-canine $\operatorname{IgM}$ and $\mathrm{IgG}$ antibodies conjugated to fluorescein isothiocianate (Nordic Immunology, lots 4691 and 3859).
Analysis of data - The association between the serological test results and the epidemical and clinical variables was verified by the Chi-square and/or Fischer Exact Test, utilizing the program EpiInfo 6.04c (Centers for Disease Control and Prevention, Atlanta, GA, 1997), and by multivariate logistic regression analysis, using the program EpiInfo Logistic Regression 6.50 (Centers for Disease Control and Prevention, Atlanta, GA, 1994), taking $\alpha=0.05$.

\section{RESULTS}

IgG antibodies were detected in $26(32.5 \%)$ of the animals, with titers 16, 64, and 256, in $11(42.3 \%), 11(42.3 \%)$ and $4(15.4 \%)$ respectively, of these animals, while for IgM, $25(31.2 \%)$ were positive of which, $6(24 \%), 12(48 \%)$ and 7 $(28 \%)$ with titers 16,64 , and 256 , respectively.

With respect to age, $39(48.7 \%)$ were under a year, 16 (20\%) were 12 to 24 months of age, and 25 (31.2\%) were 24 to 36 (incomplete) months. The distribution of reagents to IgG was $28.2 \%, 31.2 \%$, and $40 \%$ for 3 to 12 month's range, 12 to 24 , and 24 to 36 , respectively $\left(\chi^{2}=0.9803 ; p=0.6125\right)$. For IgM, the frequency of reaction was $38.5 \%, 25 \%$, and $24 \%$, respectively, for those ages $\left(\chi^{2}=1.847 ; \mathrm{p}=0.3972\right)$.

Table I presents the distribution of reagents according to sex, breed, type of environment, and exposure to other animals. There was a significant difference between the proportion of males to females reacting to $\mathrm{IgG}$; a slight

TABLE I

Number and percentage of reagent animals, attended from January to December 1998 at the Veterinary Hospital, to IgG and IgM anti-Toxoplasma gondii immunofluorescent antibody test (IFAT), according to sex, breed, environment and contact with other animals, Botucatu, 2000

\begin{tabular}{|c|c|c|c|c|c|c|c|c|c|c|c|}
\hline \multirow[t]{2}{*}{ Variable } & \multirow{2}{*}{$\begin{array}{l}\text { Total of } \\
\text { animals }\end{array}$} & \multicolumn{5}{|c|}{ IgG IFAT } & \multicolumn{5}{|c|}{ IgM IFAT } \\
\hline & & $\mathrm{N}$ & $\%$ & $\chi^{2}$ & $\mathrm{p}$ & $\overline{\mathrm{OR}}$ & $\mathrm{N}$ & $\%$ & $\chi^{2}$ & $\mathrm{p}$ & OR \\
\hline \multicolumn{12}{|l|}{$\overline{\text { Sex }}$} \\
\hline Male & 47 & 22 & 46.8 & 9.11 & 0.00 & 6.38 & 18 & 38.3 & 1.90 & 0.17 & 2.30 \\
\hline Female & 33 & 4 & 12.1 & & & & 7 & 21.2 & & & \\
\hline \multicolumn{12}{|l|}{ Breed } \\
\hline Indetermined & 62 & 21 & 33.9 & 0.04 & 0.42 & 1.33 & 23 & 37.1 & 3.26 & 0.07 & 7.72 \\
\hline Pure & 18 & 5 & 27.8 & & & & 2 & 16.7 & & & \\
\hline \multicolumn{12}{|l|}{ Environment } \\
\hline Urban & 64 & 19 & 29.7 & 0.60 & 0.22 & 0.54 & 22 & 34.4 & 0.82 & 0.36 & 2.27 \\
\hline Rural & 16 & 7 & 43.7 & & & & 3 & 18.8 & & & \\
\hline \multicolumn{12}{|l|}{ Street access } \\
\hline No & 41 & 29 & 70.7 & 8.15 & 0.00 & 5.52 & 10 & 24.4 & 3.88 & 0.02 & 0.30 \\
\hline Yes & 23 & 7 & 30.4 & & & & 12 & 52.2 & & & \\
\hline \multicolumn{12}{|l|}{ Kind of ground } \\
\hline Soil & 21 & 6 & 28.6 & 0.00 & 0.47 & 1.04 & 6 & 28.6 & 0.09 & 0.38 & 1.20 \\
\hline Cement & 36 & 10 & 27.8 & & & & 9 & 25 & & & \\
\hline \multicolumn{12}{|l|}{ Contact with cats } \\
\hline Yes & 14 & 4 & 28.6 & - & 0.50 & 0.80 & 4 & 28.6 & - & 0.54 & 0.86 \\
\hline Not & 66 & 22 & 33.3 & & & & 21 & 31.8 & & & \\
\hline \multicolumn{12}{|c|}{ Contact with birds } \\
\hline Yes & 23 & 13 & 56.5 & 7.02 & 0.00 & 4.40 & 6 & 26.1 & 0.13 & 0.36 & 0.70 \\
\hline Not & 57 & 13 & 22.8 & & & & 19 & 33.3 & & & \\
\hline \multicolumn{12}{|c|}{ Contact with rodents } \\
\hline Yes & 17 & 9 & 53 & 3.01 & 0.04 & 3.04 & 6 & 35.3 & 0.01 & 0.46 & 1.26 \\
\hline Not & 63 & 17 & 27 & & & & 19 & 30.2 & & & \\
\hline \multicolumn{12}{|c|}{ Contact with other dogs } \\
\hline Yes & 49 & 17 & 34.7 & 0.08 & 0.39 & 1.30 & 19 & 38.8 & 2.49 & 0.06 & 2.64 \\
\hline Not & 31 & 9 & 29 & & & & 6 & 19.3 & & & \\
\hline \multicolumn{12}{|l|}{ Hunting } \\
\hline Yes & 14 & 5 & 35.7 & 0.08 & 0.39 & 1.19 & 5 & 35.7 & 0.00 & 0.47 & 1.28 \\
\hline Not & 66 & 21 & 31.8 & & & & 20 & 30.3 & & & \\
\hline
\end{tabular}

$\chi^{2}$ : chi-square statistics; $p$ : $p$-value; OR: odds ratio 
preponderance of reaction among the animals of indeterminate breed; animals with no access to streets showed a higher rate of reaction to $\operatorname{IgG}$, but the opposite was observed with anti-IgM reaction; a significant degree of association in the proportion of reagents to IgG among the dogs that had contact with birds and rodents; and a tendency for higher rate for IgM reagents among the animals living with other dogs.

Table II shows results referring to the proportions of reagents to $\operatorname{IgG}$ and $\operatorname{IgM}$, according to type of feeding habits. There were no significant differences, but some figures show a tendency toward significant differences, such as the proportion of reactors to IgG among animals consumers of raw tripe and offal (odds ratio $=3.33$ ) and to IgM among animals consumers of raw milk (odds ratio $=$ 2.54 ). It should be pointed out that the animal that consumed raw goat milk showed titer 256 for IgM.

Table III shows the association between the serological reactions and the neurologic analyzed variables, where no significant associations were found.

Table IV presents only the variables that showed significative associations with the results of serology to IgG and $\operatorname{IgM}$ antibodies by multivariate logistic regression analysis.

\section{DISCUSSION}

The observed proportion of animals reagents to IgG agree with international literature. The seroprevalence of toxoplasmosis in human and animal populations is variable (Frenkel 1990). Jackson et al. (1987) found the frequency of reagents to be $19.6 \%$ among dogs in central
Scotland, and Dubey et al. (1990) cite the prevalence of reagents in the USA as being about $30 \%$ in dogs.

The frequency found in the present study is considerably lower than that found by other Brazilian authors, such as Ishizuka et al. (1974), who found 72\% in São Paulo, and Ishizuka and Yasuda (1981), with 63.8\%, also in São Paulo. Germano et al. (1985) with 91\% in Campinas, and Guimarães et al. (1992) with 47.3\% in Belo Horizonte.

As for age group differences, we found a higher rate among older dogs, in agreement with the other literature consulted. Jackson et al. (1987) observed a significant difference in animals less or more than six months of age, with $20 \%$ and $27.9 \%$ of reagent dogs, respectively. Ishizuka et al. (1974) found a higher number of positive reactors in dogs of over two years of age, while Germano et al. (1985) observed no differences, and Guimarães et al. (1992) found a higher percentage in animals over two years of age.

Higher frequency of reaction in males, in this study, is not in agreement with literature, and there seems to be no explanation for an orally transmissible disease to discriminate between the sexes (Germano et al. 1985), but the multivariate analysis of this variable shows significance only when it is associated with raw meat consumption and raw tripe and offal consumption, for IgG antibodies, and with alterations of consciousness, for IgM antibodies, showing the association of risk factors (Table IV). The tendency toward higher frequency for IgM in dogs of indeterminate breed can be explained by the fact that these animals receive less attention in their care and feeding, which have more chance of exposure to contaminated food, either offered by humans or as a result of more predatory habits toward small animals.

TABLE II

Number and percentage of reagent animals, attended from January to December 1998 at the Veterinary Hospital, to IgG and IgM anti-Toxoplasma gondii immunofluorescent antibody test (IFAT), according to feeding habits, Botucatu, 2000

\begin{tabular}{|c|c|c|c|c|c|c|c|c|c|c|c|}
\hline \multirow[t]{2}{*}{ Variable } & \multirow{2}{*}{$\begin{array}{l}\text { Total of } \\
\text { animals }\end{array}$} & \multicolumn{5}{|c|}{ IgG IFAT } & \multicolumn{5}{|c|}{ IgM IFAT } \\
\hline & & $\mathrm{N}$ & $\%$ & $\chi^{2}$ & $\mathrm{p}$ & $\overline{\text { OR }}$ & $\mathrm{N}$ & $\%$ & $\chi^{2}$ & $\mathrm{p}$ & OR \\
\hline \multicolumn{12}{|l|}{ Kind of food } \\
\hline Comercial & 15 & 3 & 20 & 1.50 & 0.47 & - & 2 & 13.3 & 3.73 & 0.16 & - \\
\hline Home made & 26 & 10 & 38.5 & & & & 11 & 42.3 & & & \\
\hline Comercial + home made & 39 & 13 & 33.3 & & & & 12 & 30.8 & & & \\
\hline \multicolumn{12}{|l|}{ Kind of home made food } \\
\hline Specially prepared & 26 & 11 & 42.3 & 0.22 & 0.63 & 1.47 & 10 & 38.5 & 0.00 & 0.96 & 1.12 \\
\hline Human & 39 & 13 & 33.3 & & & & 14 & 35.9 & & & \\
\hline \multicolumn{12}{|l|}{ Raw meat consumption } \\
\hline Yes & 27 & 12 & 44.4 & 0.64 & 0.42 & 1.73 & 8 & 29.6 & 0.59 & 0.44 & 0.58 \\
\hline No & 38 & 12 & 31.6 & & & & 16 & 42.1 & & & \\
\hline \multicolumn{12}{|c|}{ Raw tripe and offal consumption } \\
\hline Yes & 8 & 5 & 62.5 & - & 0.11 & 3.33 & 3 & 37.5 & - & 0.63 & 1.03 \\
\hline No & 57 & 19 & 33.3 & & & & 21 & 36.8 & & & \\
\hline \multicolumn{12}{|l|}{ Raw vegetable consumption } \\
\hline Yes & 2 & 0 & 0 & - & 0.39 & 0.00 & 1 & 50 & - & 0.60 & 1.74 \\
\hline No & 63 & 24 & 38.1 & & & & 23 & 36.5 & & & \\
\hline \multicolumn{12}{|l|}{ Milk consumption } \\
\hline Yes & 56 & 17 & 30.36 & 0.13 & 0.72 & 0.73 & 18 & 32.14 & 0.00 & 1.00 & 1.15 \\
\hline No & 24 & 9 & 37.5 & & & & 7 & 29.12 & & & \\
\hline \multicolumn{12}{|l|}{ Kind of milk consumed } \\
\hline Cow & 55 & 17 & 30.91 & - & 0.69 & - & 18 & 32.73 & - & 0.34 & 0.00 \\
\hline Goat & 1 & 0 & 0 & & & & 1 & 100 & & & \\
\hline \multicolumn{12}{|l|}{ Raw milk comsumption } \\
\hline Yes & 10 & 3 & 30 & - & 0.65 & 0.98 & 5 & 50 & - & 0.16 & 2.54 \\
\hline No & 46 & 14 & 30.4 & & & & 13 & 28.3 & & & \\
\hline
\end{tabular}

$\chi^{2}$ : chi-square statistics; $\mathrm{p}$ : $\mathrm{p}$-value; OR: odds ratio 
TABLE III

Number and percentage of reagent animals, attended from January to December 1998 at the Veterinary Hospital, to IgG and IgM anti-Toxoplasma gondii immunofluorescent antibody test (IFAT), according to neurologic examination, Botucatu, 2000

\begin{tabular}{|c|c|c|c|c|c|c|c|c|c|c|c|}
\hline \multirow[t]{2}{*}{ Variable } & \multirow{2}{*}{$\begin{array}{l}\text { Total of } \\
\text { animals }\end{array}$} & \multicolumn{5}{|c|}{ IgG IFAT } & \multicolumn{5}{|c|}{ IgM IFAT } \\
\hline & & $\mathrm{N}$ & $\%$ & $\chi^{2}$ & $\mathrm{p}$ & OR & $\mathrm{N}$ & $\%$ & $\chi^{2}$ & $\mathrm{p}$ & OR \\
\hline \multicolumn{12}{|l|}{ Seizures } \\
\hline Yes & 29 & 9 & 31 & 0.00 & 0.97 & 0.90 & 10 & 34.5 & 0.05 & 0.83 & 1.26 \\
\hline Not & 51 & 17 & 33.3 & & & & 15 & 29.4 & & & \\
\hline \multicolumn{12}{|l|}{ Kind of seizures } \\
\hline Focal & 6 & 3 & 50 & - & 0.26 & 2.83 & 4 & 66.7 & - & 0.14 & 5.67 \\
\hline Generalized & 23 & 6 & 26.1 & & & & 6 & 26.1 & & & \\
\hline \multicolumn{12}{|l|}{ Consciousness } \\
\hline Altered & 24 & 10 & 41.67 & 0.78 & 0.38 & 1.79 & 10 & 41.7 & 1.11 & 0.29 & 1.95 \\
\hline Normal & 56 & 16 & 28.57 & & & & 15 & 26.8 & & & \\
\hline \multicolumn{12}{|l|}{ Walking } \\
\hline Altered & 61 & 22 & 36.1 & 0.88 & 0.35 & 2.12 & 18 & 29.5 & 0.10 & 0.75 & 0.72 \\
\hline Normal & 19 & 4 & 21 & & & & 7 & 36.8 & & & \\
\hline \multicolumn{12}{|l|}{ Kind of walking change } \\
\hline Absent & 48 & 16 & 33.3 & - & 0.29 & 0.58 & 14 & 29.2 & - & 0.58 & 0.93 \\
\hline Postural incoordination & 13 & 6 & 46.2 & & & & 4 & 30.8 & & & \\
\hline \multicolumn{12}{|l|}{ Hand-cart test } \\
\hline Altered & 30 & 12 & 40 & 0.74 & 0.39 & 1.71 & 12 & 40 & 1.12 & 0.29 & 1.90 \\
\hline Normal & 50 & 14 & 28 & & & & 13 & 26 & & & \\
\hline \multicolumn{12}{|l|}{ Pupilar reflex } \\
\hline Altered & 53 & 18 & 33.9 & 0.02 & 0.89 & 1.22 & 17 & 32.1 & 0.00 & 0.97 & 1.12 \\
\hline Normal & 27 & 8 & 33.7 & & & & 8 & 29.6 & & & \\
\hline \multicolumn{12}{|c|}{ Kind of pupilar reflex change } \\
\hline Absent & 24 & 8 & 33.3 & 0.04 & 0.84 & 0.95 & 11 & 45.8 & 2.74 & 0.09 & 3.24 \\
\hline Reducted & 29 & 10 & 34.4 & & & & 6 & 20.1 & & & \\
\hline
\end{tabular}

$\chi^{2}$ : chi-square statistics; $\mathrm{p}$ : p-value; OR: odds ratio

TABLE IV

Risk fators for positive serology to IgG and IgM antibodies to Toxoplasma gondii in dogs, attended from January to December 1998 at Veterinary Hospital, Botucatu, 2000

\begin{tabular}{llccc}
\hline Kind of antibodies & Variables & OR & CI (95\%) & $\mathrm{p}$ \\
\hline IgG & Sex & 0.1 & $0-0.5$ & 0.0065 \\
& Raw meat consumption & 0.2 & $0-1.0$ & 0.0496 \\
\multirow{2}{*}{ IgM } & Raw tripe and offal consumption & 19.7 & $1.8-215.0$ & 0.0145 \\
& Sex & 0.2 & $0-0.8$ & 0.0236 \\
& Consciousness & 4.8 & $1-22.5$ & 0.0475 \\
\hline
\end{tabular}

OR: odds ratio; $\mathrm{CI}(95 \%)$ : confidence interval at $95 \%$ for odds ratio; $\mathrm{p}$ : $\mathrm{p}$-value

With regard to environment, the frequency of reagents was higher among those from a rural area, and those raised with access to dirt, although this last condition alone did not presents significant difference. Contact with small animals, principally birds and rodents, can lead to predatory habits and therefore ingestion of tissues with cysts of $T$. gondii. Svoboda and Svobodová (1987) found less antibodies in dogs kept in apartments, and more in animals with the habit of hunting. Germano et al. (1985) and Guimarães et al. (1992) point that the high receptivity of dogs for toxoplasma, due to the facility of ingestion of tissue and to contact with contaminated soil. Xenophilia could be an important means of transmission of the disease (Martins \& Vianna 1998).

The results here point out a higher frequency of antibodies in those animals that are fed home-made food, specially when meat or offal was included, which agrees with literature (Germano et al.1985, Jackson et al. 1987).
None of the variables studied in the neurological examinations demonstrated a significant association with the numbers of reagent animals, by univariate analysis with Chi-Square Test, but the multivariate analysis shows that IgM titers are more prevalent in dogs with altered consciousness (Table IV).

Although it is not possible to be certain that every case is one of clinical toxoplasmosis, given the possibility of neurological symptomatology of other infections, such as distemper, these results demonstrate the importance of toxoplasmosis in the canine species and the risk to public health, pointing out probable common sources of infection for both humans and canines, as well as the possibility of direct transmission from dog to man, since in its acute and generalized form there could occur elimination of viable parasites by different secretions and excretions, as well as the mechanical vectoring of oocysts after ingestion of cat feces. 


\section{REFERENCES}

Camargo ME 1974. Introdução às técnicas de imunofluorescência. Rev Bras Patol Clín 10: 143-169.

Dubey JP, Greene CE, Lappin MP 1990. Toxoplasmosis and neosporosis. In CE Greene, Infectious Diseases of Dog and Cat, WB Saunders, Philadelphia, p. 830-835.

Freire RL, Navarro IT, Vidotto O, Tudury EA, Vianna CC 1992. Prevalência de anticorpos anti-Toxoplasma gondii em cães atendidos no Hospital Veterinário da UEL-PR. Semina Ci Agr 13: 65-69.

Frenkel JK 1990. Transmission of toxoplasmosis and the role of immunity in limiting transmission and illness. J Am Vet Med Assoc 196: 233-240.

Germano PML, Erbolato EB, Ishizuka MM 1985. Estudo sorológico da toxoplasmose canina pela prova de imunofluorescência indireta na cidade de Campinas, 1981. Rev Fac Med Vet Zoot Univ São Paulo 22: 53-58.

Guimarães AM, Ribeiro MFB, Lima JD, Cury MC, Spiewak $\mathrm{G}$ 1992. Frequiência de anticorpos anti-Toxoplasma gondii em cães de Belo Horizonte, Minas Gerais. Arq Bras Med Vet Zoot 44: 67-68.

Ishizuka MM, Yasuda PH 1981. Incidência de infecção por Toxoplasma gondii em cães do município de São Paulo. Rev Fac Med Vet Zoot Univ São Paulo 18: 161-165.

Ishizuka MM, Miguel O, Brogliato DF 1974. Prevalência de anticorpos anti-toxoplasma em soros de cães do município de São Paulo. Rev Fac Med Vet Zoot Univ São Paulo 11:
115-125.

Jackson MH, Hutchison WM, Siim JC 1987. Prevalence of Toxoplasma gondii in meat animals, cats and dogs in Central Scotland. Br Vet J 143: 159-165.

Lindsay DS, Dubey JP, Butler JM, Blagburn BL 1997. Mechanical transmission of Toxoplasma gondii oocysts by dogs. Vet Parasitol 73: 27-33.

Martins CS, Viana JA 1998. Toxoplasmose-O que todo profissional de saúde deve saber - Revisão. Clín Vet 15: 33-37.

Navarro IT, Freire RL, Vidotto O, Ogawa L, Kano FS 1997. Estudo comparativo entre soro e plasma na pesquisa de anticorpos antiToxoplasma gondii pela técnica de imunofluorescência indireta em cães atendidos no Hospital Veterinário da Universi-dade Estadual de Londrina - PR, 1996. Semina Ci Agr 18: 15-21.

Salata E, Yoshida ELA, Pereira EA, Corrêa FMA 1985. Toxoplasmose em animais silvestres e domésticos da região de Botucatu, Estado de São Paulo, Brasil. Rev Inst Med Trop São Paulo 27: 20-22.

Svoboda M, Svobodová V 1987. Effects of breed, sex, age, management and nutrition on the incidence of Toxoplasma gondii antibodies in dogs and cats. Acta Vet Brno 56: 315-330.

Swango LJ, Bankemper KW, Kong LI 1992. Infecções bacterianas, riquetsiais, protozoais e outras. In SJ Ettinger, Tratado de Medicina Interna Veterinária: Moléstias do Cão e Gato, Manole, São Paulo, p. 296-298.

Tenter AM 1999. Current knowledge on the epidemiology of infections with Toxoplasma. Tokai J Exp Clin Med 23: 391. 
